\title{
Study on the Integration of Financial Ethics Education in Financial Institutions*
}

\author{
Xiaoyu Liu \\ Harbin Finance University \\ Harbin, China
}

\begin{abstract}
As the new strength of financial institutions, college students can begin to inculcate and strengthen the ethical and moral concepts from the university stage, and can restrain the moral bankruptcy of financial practitioners from the source. Therefore, it is necessary to discuss how to conduct financial ethics education in financial institutions to improve the moral quality of financial practitioners.
\end{abstract}

Keywords-financial ethics; case teaching; ethical code

\section{INTRODUCTION}

The ethical issues in the financial field are accompanied by financial and economic behaviors, and there is no financial ethics without financial practice, and there is no financial activity without financial ethics. Financial ethics profoundly reflects the inner culture and charm of finance. Financial ethics is the product of financial transactions and the guarantee of smooth financial transactions. Therefore, financial ethics inevitably involves the operation of financial market and the participants of financial market. That is to say, the ethics of financial markets has not only show the personal behavior, good and evil also show the trading behavior, corporate governance structure, and the institutional arrangement of financial markets, the government's financial regulation, and many other aspects of value judgment.

\section{THE NECESSITY OF EDUCATION OF FINANCIAL ETHICS}

\section{A. Financial Ethics Education Is a Realistic Need for the Development of the Financial Industry}

Along with the rapid development of the financial industry, the number of financial institutions, financial products innovation, but also some bad phenomena appeared at the same time, for example, some of the ethical and moral low quality workers for illegal manipulation, the phenomenon such as fraud and false advertising, mice storehouse in the securities market, etc. They abuse their

*Foundation item: The research project of the basic scientific research project of the province of Harbin Finance University, which is based on the financial ethics perspective, the research stage of the financial development evaluation of the county area(2017-KYYWF-0088); The research on the innovation of financial ethics education in financial institutions under the background of "Internet plus" in the "13th five-year plan" of education science in heilongjiang province. Periodic results. (GJD1316020) authorities by bad loans, the use of position to divert the customer stock, bond or unit of capital stock speculation and participate in the financial fraud, embezzlement, bribery; moreover the internal and external collusion to rob this unit vaults and so on. It allows the public to lose confidence in the financial industry, to say, has a negative effect on the financial industry, just think, if a country's financial market is a fraud, it will lead to financial activity cannot go smoothly, the long since this will affect the development of a country's financial industry, therefore, as a teacher in university, should guide students to learn lessons from the financial illegal activity and lay a foundation for further work in the financial industry, the teacher should be in the financial professional education and practice combine financial and ethical fully, lets the student to maintain a healthy financial activity an important responsibility.

\section{B. Financial Ethics Education Helps College Students to Form Correct Values}

The students in the financial industry are the main force of the financial industry and the source of fresh blood in the future financial industry. Their ethical and moral quality determines the development direction of the financial industry in the future. In university stage, these students are in a special growth stage of formation of the outlook on life and values, is the best period of high-quality financial talents cultivation, if we can strengthen their ethics education during this period, has achieved a certain significant. Financial undergraduate course colleges and universities in personnel training, therefore, to strengthen the financial professional ethics education, the teacher in the interpretation of the professional knowledge at the same time, pay attention to financial ethics education to students, let moral education throughout the whole teaching activities, stimulate students' professional consciousness, make them form the correct values. Cultivate students' financial ethics and ethics, and make them aware of the responsibilities and obligations of financial institutions and financial practitioners.

\section{Financial Ethics Education Promotes the Healthy and Orderly Development of China's Financial Market}

Our students are the future investors of financial market, and education of financial ethics directly influences investors' investment philosophy. The connotation of traditional financial investment and ethical investment is different. In general, the financial investment decisions only 
focusing on financial returns and risk, investment means the social responsibility and ethics, can be understood as ethical or social standard to select and manage usually consists of the shares of the company's investment portfolio. Ethical investors not only care about the high and low levels of expected financial returns, but also about the company itself. As a result of practice, companies that invest through ethical investment standards generally operate well without crises or scandals. It can be seen that financial investment should be an organic combination of rational investment in technology and ethical investment, which reflects the social responsibility of the financial industry and employees. In recent years, the financial market in our country, all kinds of speculation and violation behavior, mainly for insider trading and excessive speculation, market manipulation and securities fraud behavior, not only has violated the financial markets open, fair, justice, the basic code of ethics, and hinder the healthy and orderly development of financial markets. Both institutional investors and individual investors, when they only to borrowers and their effectiveness to objective assessment of the risks and benefits of investment, and regardless of investment brought about by the bad demonstration effect, this kind of behavior is bound to face ethical challenges and condemnation, the order of financial market and reputation will be influenced by any unhealthy tendencies and further affect the optimal allocation of resources in financial markets.

\section{FINANCIAL ETHICS EDUCATION STATUS ANALYSIS}

In the operation of China's financial industry, the role of financial ethics has not attracted enough attention. It was not until the 21st century that the domestic theorists began to recognize the importance of financial ethics. However, in the process of financial teaching, domestic colleges and universities have no financial ethics at all, and financial ethics has not been listed as a required course in the current financial undergraduate stage. They are more in accordance with the traditional way of cultivation, focusing only on the cultivation of students' professional knowledge.

For a long time, China's financial industry has been playing a market game without ethical norms, so the ethical aspects of financial markets have been in a state of chaos and disorder. And because the market economy system, constraint mechanism and legal system is not sound reasons, led to the good faith, fair and just these important professional ethics on financial professionals lack of phenomenon is very serious. Our traditional financial universities ignored in the process of cultivation or no financial professional ethics education and service awareness training, so that the university graduates are hard to adapt to the requirement of future financial practice department. In this environment, in the financial discipline teaching widely into financial ethical content is very necessary, cultivation of contemporary college students make it have good financial ethics consciousness also appears especially important.

In the process of financial personnel training, financial institutions strengthen students' cognition of financial ethics, and strengthen the cultivation of students' financial professional ethics, which has special significance. Firstly, financial market is a place where greed is very easy to breed. Only people with good financial professional qualities meet the needs of commercial financial institutions for talents. This requires financial colleges and universities should adhere to the talent of education high quality, a high skill of financial, make financial personnel not only have excellent professional skills, but also has the professional ethics of consciousness and noble professional ethics moral integrity. Only with solid professional skills and high financial professional ethics can financial employees meet the needs of financial talents in the modern financial industry. Second, college is the best time to shape high-quality financial talents. At the university stage, students' age characteristics make them have the objective conditions to accept education guidance, and they are still in the formation stage of outlook on life and values. In this period, strengthening the financial ethics of college students' education, to improve their financial ethics and morality, often can achieve the result of half the effort.

\section{THE COUNTERMEASURE OF STRENGTHENING THE EdUCATION OF COLLEGE STUdENTS' FINANCIAL ETHICS IN FINANCIAL INSTITUTIONS}

\section{A. Seting up Education Mode with Project-oriented and Case Teaching}

Project oriented refers to the teaching of financial projects or tasks as teaching the direction of the dominant, the message of the projects or tasks to and from personnel of course of financial ethics requirements closely, this kind of project oriented teaching method can not only stimulate students' interest in learning, students learn independently, and make students learn more with pertinence and practicability, so as to effectively improve the students' creative ability, to cultivate students' ability to analyze and solve practical problems, to make students understand the importance of financial ethics code of ethics, improve student financial ethics cultivation. Project oriented and at the same time combined with case teaching to carry out teaching activities, guide students from several aspects to discuss, students through case content can understand financial ethics knowledge related to the financial work can not only realize the integration of teaching and practice teaching, case is the carrier of education fully combined with professional knowledge and ethics. And real cases can help students relate what they have learned to the realities of financial careers. The selection of cases provide students according to their own interest, should not only pay attention to the authenticity, and should pay attention to, at the same time, the core of knowledge in each course to highly correlated, so that the students' knowledge and ethical education better organic link, to promote students' autonomous learning. In addition, teachers can establish a systematic financial ethics case library. If used in the case of professional knowledge learning category, to more than a course can be more courses Shared the same case, respectively from the Angle of different knowledge, multiple points of view are discussed, also can be in a special financial ethics courses focused on. Special teachers are responsible for the construction and maintenance. The 
education module of financial ethics can also be imbedded in different professional courses through case discussion.

\section{B. Professional Curriculum Teaching Integrates Ethics Education}

The implementation of the education mode, type of specialized course infiltration must be a party in the common course of professional basic course and humanistic quality and economic ethics module content is added to the other party and blend in ethical problems organically, such as professional curriculum design, graduation design, curriculum teaching practice, and other links. Financial ethics education's purpose is to create a complete theoretical framework of financial ethics and teaching system, that is to make students through the course, finance or related field systematically through the perspective of ethics throughout the financial system of operation, a deep reflection and review of the dialectical relationship between financial and ethics, and understand the ethical conflicts within the financial system and the ethical relationship between stakeholders, fully grasp the core of financial ethics category and the basic value standard, to establish a conducive to financial steady operation, public welfare and social harmonious development of new financial rules of ethics. Because financial ethics problems to be solved is the implementation of the projects and economic activities, which is closely linked to financial ethics quality education throughout the course of curriculum, both to improve the students' interest in learning the course, and can realize the combination of theory and practice, the maximum at the same time also to train the students' ability to use knowledge to solve practical problems. Taking the course teaching of international trade practice as an example, following the teaching path from theory to practice, it organically integrates the relevant content of international trade ethics. On the one hand, the teacher combines professional theoretical study with students to explore the ethical issues in international trade theory. For example, how to view and mitigate the disputes and conflicts between free trade theory and trade protectionism, as the main body of international trade. It should fulfill the social responsibility of the enterprise and so on, students in the process of thinking, debate, accept the ethical concept of edification.

\section{CONCLUSION}

It should carry on the investment financial ethics education, set the new idea of socially responsible investing, make them realize financial ethics investment contributes to the most valuable of the financial resources allocation and use, is conducive to cultivating enterprise good social sense of responsibility, create a harmonious and fair competition environment

\section{REFERENCES}

[1] Edward J.Kane, Using Deferred Compensation to Strengthen the Ethics of Financial Regulation, Journal of Banking and Finance,26, 2002, pp.1919 1933 .
[2] Edward J.Kane, Regulation andSupervision:An Ethical Perspective, NBERWorking Paper, No.13895, 2008, pp.1 31 .

[3] Dean, K. L.\& Beggs, J.M.University professors and teaching ethics: Conceptualizations and expectations. Journal of Management Education. 2006 